\title{
Immunomodulatory Effects of Diterpenes and Their Derivatives Through NLRP3 Inflammasome Pathway: A Review
}

\section{OPEN ACCESS}

Edited by:

Wilson Savino,

Oswaldo Cruz Foundation

(Fiocruz), Brazil

Reviewed by:

Yue Zhang

Johns Hopkins Medicine,

United States

Shima Shahjouei,

Geisinger Health System,

United States

*Correspondence:

Wojciech Koch

kochw@interia.p

Javad Sharifi-Rad

javad.sharifirad@gmail.com

Specialty section:

This article was submitted to Nutritional Immunology,

a section of the journal

Frontiers in Immunology

Received: 12 June 2020

Accepted: 17 August 2020

Published: 25 September 2020

Citation:

Islam MT, Bardaweel SK,

Mubarak MS, Koch W,

Gawel-Beben K, Antosiewicz B and

Sharifi-Rad J (2020)

Immunomodulatory Effects of

Diterpenes and Their Derivatives

Through NLRP3 Inflammasome

Pathway: A Review

Front. Immunol. 11:572136. doi: 10.3389/fimmu.2020.572136

\begin{abstract}
Muhammad Torequl Islam ${ }^{1,2}$, Sanaa K. Bardaweel ${ }^{3}$, Mohammad S. Mubarak ${ }^{4}$, Wojciech Koch ${ }^{5 *}$, Katarzyna Gawet-Beben ${ }^{6}$, Beata Antosiewicz ${ }^{6}$ and Javad Sharifi-Rad ${ }^{7 *}$

${ }^{1}$ Laboratory of Theoretical and Computational Biophysics, Ton Duc Thang University, Ho Chi Minh City, Vietnam, ${ }^{2}$ Faculty of Pharmacy, Ton Duc Thang University, Ho Chi Minh City, Vietnam, ${ }^{3}$ Department of Pharmaceutical Sciences, School of Pharmacy, The University of Jordan, Amman, Jordan, ${ }^{4}$ Department of Chemistry, The University of Jordan, Amman, Jordan, ${ }^{5}$ Chair and Department of Food and Nutrition, Medical University of Lublin, Lublin, Poland, ${ }^{6}$ Department of Cosmetology, University of Information Technology and Management in Rzeszów, Rzeszów, Poland, ${ }^{7}$ Zabol Medicinal Plants Research Center, Zabol University of Medical Sciences, Zabol, Iran
\end{abstract}

Nucleotide-binding oligomerization domain-like receptor family pyrin domain-containing protein (NLRP) inflammasomes are involved in the molecular pathogenesis of many diseases and disorders. Among NLRPs, the NLRP3 (in humans encoded by the NLRP3 gene) is expressed predominantly in macrophages as a component of the inflammasome and is associated with many diseases, including gout, type 2 diabetes, multiple sclerosis, atherosclerosis, and neurological diseases and disorders. Diterpenes containing repeated isoprenoid units in their structure are a member of some essential oils that possess diverse biological activities and are becoming a landmark in the field of drug discovery and development. This review sketches a current scenario of diterpenes or their derivatives acting through NLRPs, especially NLRP3-associated pathways with anti-inflammatory effects. For this, a literature survey on the subject has been undertaken using a number of known databases with specific keywords. Findings from the aforementioned databases suggest that diterpenes and their derivatives can exert anti-inflammatory effects via NLRPs-related pathways. Andrographolide, triptolide, kaurenoic acid, carnosic acid, oridonin, teuvincenone $F$, and some derivatives of tanshinone IIA and phorbol have been found to act through NLRP3 inflammasome pathways. In conclusion, diterpenes and their derivatives could be one of the promising compounds for the treatment of NLRP3-mediated inflammatory diseases and disorders.

Keywords: diterpenes, inflammation, mitochondrial dysfunction, NLRP3, mechanism of action

\section{INTRODUCTION}

Inflammation, the body's natural response to harmful stimuli, arises in tissues due to traumatic, infectious, post-ischemic, toxic, or autoimmune injuries. To restore the normal tissue functions during the harmful inflammatory conditions, clearance of inflammatory cells, along with pro-inflammatory signaling pathways, are required (1). The nucleotide-binding oligomerization domain-like receptor family pyrin domain-containing proteins (NLRPs), specifically NLRP3, 
a cytosolic innate immune signaling receptor, have been detected at elevated levels in several inflammatory diseases, such as chronic infantile neurological cutaneous and articular (CINCA) syndrome, familial cold auto-inflammatory syndrome (FCAS), keratoendotheliitis fugax hereditaria, Muckle-Wells syndrome (MWS), neonatal onset multisystem inflammatory disease (NOMID) $(2,3)$, and familial Mediterranean fever (4). In addition, NLRP3 has been associated with gout (5), type 2 diabetes, multiple sclerosis, atherosclerosis (6), and Alzheimer's, Parkinson's, and prion diseases (7-9). Furthermore, the deregulation of NLRP3 is associated with carcinogenesis, such as hepatocellular carcinoma $(10,11)$. Thus, the pharmacological inhibition of NLRP3 activity may possibly present a promising approach for the management and cure of inflammatory and other related diseases in both humans and animals (12).

Non-steroidal anti-inflammatory drugs (NSAIDs) are the most used medications for the treatment of inflammation and related diseases. However, NSAIDs cause many adverse effects, including gastrointestinal complications, immunodeficiency, and humoral disturbances, which may limit their use in certain patients (1). The natural products or their derivatives are comparatively safe; therefore, these can be considered as potential platforms for the discovery with anti-inflammatory properties (13). Among plant metabolites, essential oils (EOs) have gained much attention due to their possible biomedical applications. Diterpenes, a category of components present in some EOs, which contain repeated isoprenoid units in their structure and modulate diverse biological activities, are becoming a landmark in the field of EOs research (14-16).

Recently, Tricarico and coworkers suggested that isoprenoids may exert their effect by modulating different pathways in the biological systems primarily by increasing the expression of various markers for apoptosis, cytokines, mitochondrial dysfunction, NLRP3, as well as nitric oxide (NO) (17). Based on the preceding discussion and the importance of the NLRP3 inflammasome in the pathogenesis of gout and neuroinflammation occurring in protein misfolding diseases, such as Alzheimer's and Parkinson's, among others, in this review, we have sketched a current scenario of diterpenes or their derivatives acting through NLRPs, especially NLRP3-associated pathways with anti-inflammatory effects.

\footnotetext{
Abbreviations: NLRP3, NOD-like receptor pyrin domain-containing protein 3; CINCA, chronic infantile neurological cutaneous and articular; FCAS, familial cold auto-inflammatory syndrome; MWS, Muckle-Wells syndrome; NOMID, neonatal onset multisystem inflammatory disease; NSAIDs, non-steroidal antiinflammatory drugs; Eos, essential oils; NO, nitric oxide; LPS, lipopolysaccharide; MCP-1, monocyte chemoattractant protein-1; VCAM-1, vascular cell adhesion molecule-1; ROS, reactive oxygen species; TXNIP, thioredoxin-interacting protein; PPAR- $\alpha$, peroxisome proliferator-activated receptor- $\alpha$; ASK1, apoptosis signalregulating kinase 1 ; MAPK, mitogen-activated protein kinase; cNOS, constitutive NO synthase; TNF- $\alpha$, tumor necrosis factor-alpha; NF- $\kappa$, nuclear factor kappa B; CDAA, choline-deficient, L-amino acid defined; HMGP1, high-mobility group protein 1; TLR4, toll-like receptor 4; COX-2, cyclooxygenase-2; TGF- $\beta$, tumor growth factor beta; iNOS, inducible nitric oxide synthase; MIP-1 $\alpha$, macrophage inflammatory protein 1-alpha; PKC, protein kinase C; APP, amyloid precursor protein; Nrf2, nuclear factor erythroid 2; MDA, malondialdehyde; SREBP-1, sterol regulatory element-binding protein 1 ; $\mathrm{HMGB} 1$, high-mobility group protein $\mathrm{B} 1$; TIMP-1, tissue inhibitor of metalloproteinase-1.
}

\section{SEARCH STRATEGY}

A literature search was conducted through June 2020 by means of a number of well-known databases, such as Google Scholar, PubMed, Scopus, ScienceDirect, Web of Science, the American Chemical Society, and ClinicalTrials.gov, using the keywords "diterpenes or diterpenoids" and "diterpene derivatives," combined with "NLRP3 or NLRP3 inflammasome." No language restrictions were imposed. The following are the inclusion and exclusion criteria of this study.

\section{Inclusion Criteria}

- Studies with diterpenes and their derivatives or preparations acting against NLRP3;

- Studies (in vitro, ex vivo, or in vivo) with or without using experimental animals, including humans and their derived tissue and cells;

- Studies that utilized single and/or multiple cell lines or animals;

- Studies with diterpenes isolated from plants/other natural sources;

- Diterpenes or their derivatives joint effects with other substances (including diterpenes, drugs, or chemicals/biochemicals);

- Studies with or without proposing activity mechanisms.

\section{Exclusion Criteria}

- Studies with extracts without mentioning diterpene contents;

- Studies with essential oils other than diterpenes;

- Duplication of data and titles and/or abstracts not meeting the inclusion criteria;

- Diterpenes acting against NLRPs other than NLRP3;

- Diterpenes with other studies uncovering the current topic.

\section{NLRP3-MEDIATED INFLAMMATORY PATHWAYS}

Macrophages stimulated by priming stimuli, such as ligands for toll-like receptors (TLRs), NOD-like receptors (NLRs) (e.g., NOD-1 and-2), or cytokine receptors, can activate nuclear factor kappa B (NF-кB). The signaling molecules MyD88 and TRIF of the NF- $\kappa \mathrm{B}$ signaling pathway regulate the induction of NLRP3 and pro-interleukin 1 beta (IL-1 $\beta$ ) in response to TLR ligands (18). However, the apoptotic signaling molecules caspase8 and fas-associated protein with death domain (FADD) are also required for the induction of the NLRP3 during the priming process (19). Priming signals triggering c-Jun N-terminal kinase 1 (JNK1)-mediated NLRP3 phosphorylation are a critical event for NLRP3 self-association and inflammasome activation (20).

Reactive oxygen species (ROS) are proposed as a common signal for NLRP3 inflammasome (21). Mitochondrial dysfunction and mitochondrial ROS (mtROS) production are dispensable in NLRP3 inflammasome activation (22). Besides this, the mitochondria can co-localize with the NLRP3 inflammasome. Still, the mechanism associated with lysosomal disruption to NLRP3 inflammasome activation remains unclear. It has been proposed that the active lysosomal enzymes released 
into the cytosol may trigger NLRP3 inflammasome activation after the phagocytosis of a particulate matter. Lipopolysaccharide (LPS) can result in NLRP3-mediated IL-1 $\beta$ processing and secretion in a P2X purinoceptor 7 (P2X7) independent manner (23). Figure 1 represents the possible NLRP3-mediated inflammatory pathways.

\section{DITERPENES MODULATE NLRP3 INFLAMMASOME PATHWAYS: LITERATURE FINDINGS}

Research findings revealed that phytanol (Compound 1) and phytanyl amine (Compound 2) reduce the expression of NLRP3, along with interleukin (IL)-6, monocyte chemoattractant protein-1 (MCP-1), keratinocyte chemoattractant (KC), macrophage inflammatory protein 1 (MIP-1), and lipopolysaccharide-induced CXC chemokine (LIX, also GARG-8) (24). Additionally, reduction of the release of B-lymphocyte chemoattractant (BLC), T-cell activation3 chemokines tricarboxylic acid (TCA), IL-4, IL-12, and tissue inhibitor of metalloproteinase-1 (TIMP-1) in BALB/c mice was observed. In a similar fashion, the heartwood of Taiwan fir (diterpene content $0.9 \%$ ) was found to lower NLRP3 inflammasome-derived IL-1 $\beta$ secretion induced by LPS and adenosine triphosphate in mouse macrophages (25). It also lowered the levels of IL-1 $\beta$ precursor and reduced the secretion of NLRP3 inflammasome-derived IL-1 $\beta$ and adenosine triphosphate (26). Figure 2 shows the structures of diterpenes or diterpenoids and their derivatives involved in this investigation.

Triptolide (Compound 3) significantly reduced the serum levels of IL-1 $\beta$ and IL-18, along with NLRP3 and toll-like receptor 4 (TLR4), expressions in female Sprague-Dawley rats (27). It may prevent the progression of immunoglobulin A (IgA) nephropathy by ameliorating the inflammasome-mediated proinflammatory cytokine production, thus providing new insight into the treatment of this disease (28). Moreover, it exerted a cardio-protective effect in C57/BL6 mice via the attenuation of transverse aortic constriction-induced myocardial remodeling. This effect (a) enhanced cardiac diastolic and systolic functions, (b) activated the pro-fibrotic tumor growth factor 1 beta (TGF$1 \beta$ ) pathway, (c) suppressed the NLRP3 inflammasome and inflammatory mediators of IL-1 $\beta$, IL-18, MCP-1, and vascular cell adhesion molecule-1 (VCAM-1), and (d) dose-dependently inhibited macrophage infiltration (29). In a recent study, it has been found to inhibit the NLRP3-TGF1 $\beta$-Smad pathway, suggesting that this compound might be an alternative option for cardiac fibrosis via targeting the NLRP3 inflammasome (30). Furthermore, it down-regulated NLRP3 by targeting hsa-miR$20 \mathrm{~b}$ in male C57BL/6 mice and in THP-1 cells (31).

Tanshinone IIA (Compound 5) at $0-2.5 \mu \mathrm{g} / \mathrm{ml}$ exerted a protective effect by down-regulating NLRP3, caspase-1 (CASP1), IL-1 $\beta$, and IL-18 in BV-2 cells (32). The male Sprague-Dawley rats $(n=15)$ treated with this compound at $10 \mathrm{mg} / \mathrm{kg} /$ day (i.p.) for 1 week down-regulated tumor necrosis factor alpha (TNF- $\alpha$ ), IL-4, TLR4, MyD88, NLRP3, and NF-кB p65 expression levels and up-regulated IL-10, tumor growth factor-beta (TGF- $\beta$ ), phosphatase and tensin homolog (PTEN), phosphoinositide 3-kinase (PI3K), and AKT (also called protein kinase B) phosphorylation levels (33). Liu and coworkers have recently shown that in A549 cells, paclitaxel (Compound 6) can cause apoptotic cell death by ROS-induced caspase- 3 activation via the activated apoptosis signal-regulating kinase 1 (ASK1)/p38 mitogen-activated protein kinase (MAPK) signaling pathway (25). On the other hand, sodium tanshinone IIA sulfonate (Compound 4) reduced the overproduction and overexpression of cardiac ROS and thioredoxin-interacting protein (TXNIP), respectively, through diminishing the Janus kinase 2 (JAK2)-signal transducer and activator of transcription 3 (STAT3)/insulin signaling/peroxisome proliferator-activated receptor- $\alpha$ (PPAR- $\alpha)$ pathway in Beagle dogs (34). In another study, kaurenoic acid (Compound 7) restored the production of nitric oxide $(\mathrm{NO})$ in a constitutive $\mathrm{NO}$ synthase- (cNOS-) dependent fashion, increased the formation of IL-1 $\beta$, and elevated the expression of NLRP12 in Leishmania amazonensis infected $\mathrm{BALB} / \mathrm{c}$ mice (35). Phorbol myristate acetate (Compound 8) at $100 \mathrm{nM}$ down-regulated the mRNA expression of CASP1, IL-1 $\beta$, IL-18, myeloid leukemia cell differentiation protein 1 (MCL1), NLRP3, as well as PYCARD expression in BALB/cMlac mice neutrophil cells (36). In contrast, geranylgeraniol (Compound 9), diterpenoid alcohol, at $50 \mu \mathrm{M}$ was found to reduce the expression of NLRP3 gene and mitochondrial dysfunction-linked programmed cell death in a neuronal cell line (Daoy) (37).

Andrographolide (Compound 10), the bitter diterpene lactone, at 7.5 and $15 \mathrm{mg} / \mathrm{kg}$ exerted an anti-colitis and antitumor effect by lowering the expression of cleaved CASP1, IL-1 $\beta$, and mitochondrial membrane potential collapse via the PIK3CA-AKT1-MTOR-RPS6KB1 pathway. It additionally increased the disruption of NLRP3-PYCARD-CASP1 complex formation and mitophagy in macrophages, inactivated the NLRP3 inflammasome, and induced autophagy in mice (38). In another study, andrographolide was also seen to downregulate the expression of TNF- $\alpha$, IL- $1 \beta$, and NLRP3 and suppressed ROS-mediated NF- $\kappa \mathrm{B}$ expression in ovalbumin (OVA)-induced female C57/BL6 mice and BMDM cells (39). Furthermore, a recent study in mice HepG2 cells demonstrated that this diterpene lactone exhibits a hepatoprotective effect in choline-deficient, L-amino acid defined (CDAA)-fed mice; this was accomplished by reducing the hepatic inflammation and fibrosis. It also lowered the hepatic mRNA levels of both pro-inflammatory and pro-fibrotic genes, as well as hepatic macrophage infiltration, and reduced the expression of inflammasome genes, IL- $1 \beta$ expression through NF-кB inhibitory pathway, and inflammasome disassembly (40). In addition, research findings revealed that Compound 10 (a) lowers the overexpression of LPS-induced high-mobility group protein 1 (HMGB1), TLR4, NF-кB, cyclooxygenase-2 (COX-2), inducible nitric oxide synthase (iNOS), and NLRP3, (b) suppresses the overexpression of microglial macrophage inflammatory protein 1-alpha (MIP-1 $\alpha$ ) and P2X7 receptor, along with its downstream signaling mediators, including CASP1 and mature IL-1 $\beta$, and (c) modulates the expression of protein markers, such as protein 


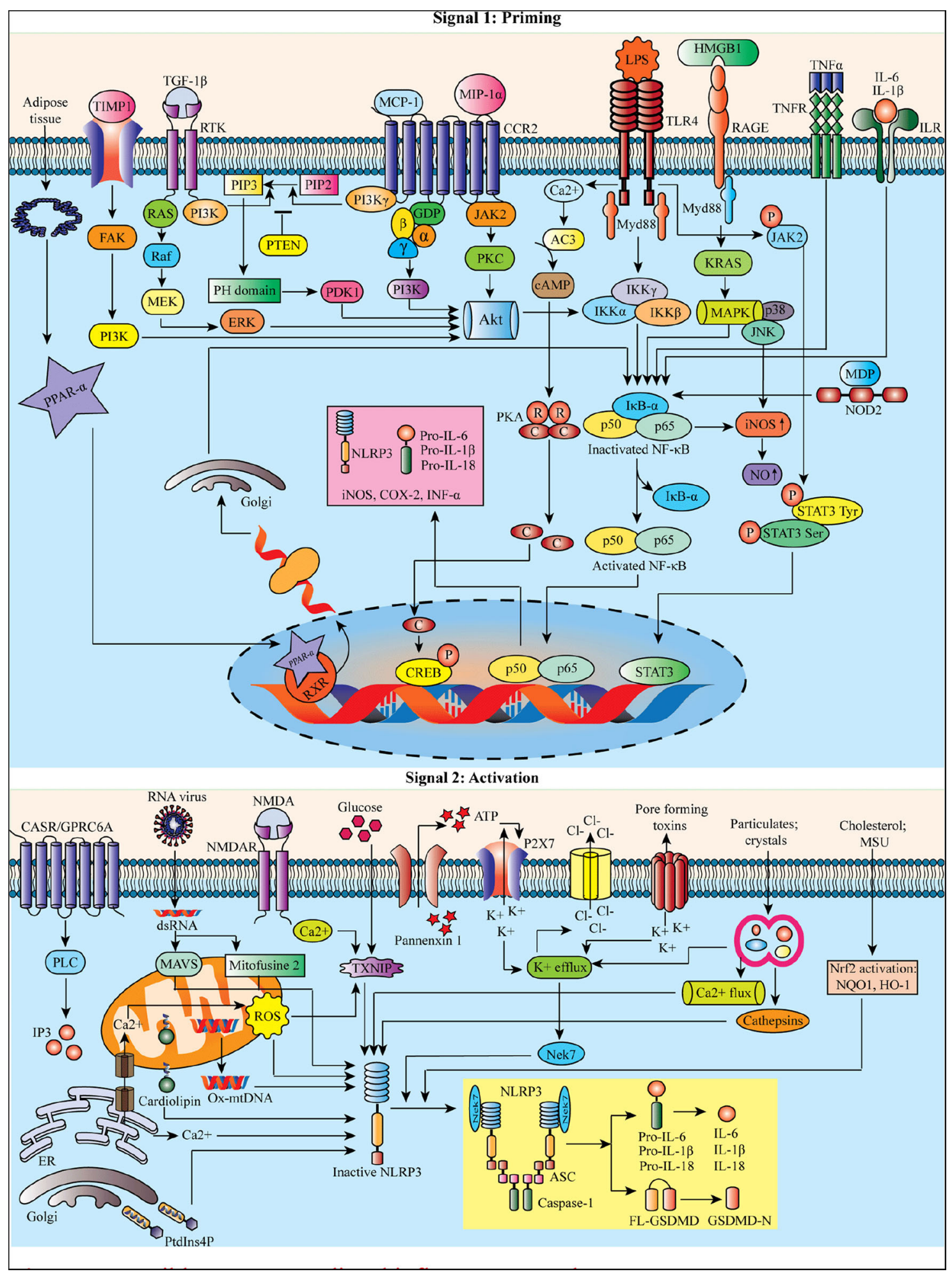

FIGURE 1 | Possible NLRP3-mediated inflammatory pathways. 


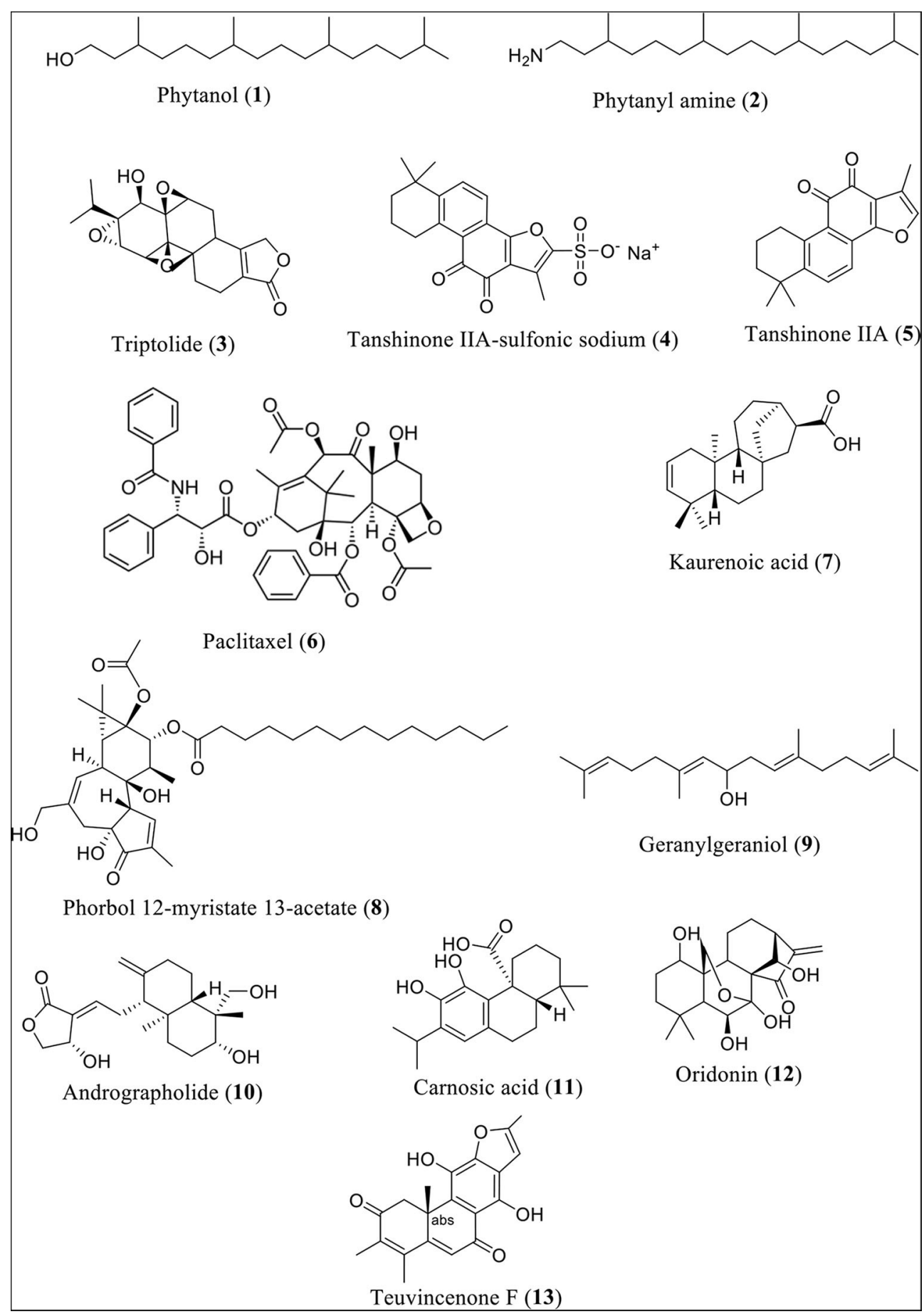

FIGURE 2 | Structures of some diterpenes or diterpenoids and their derivatives.

kinase C (PKC), phosphorylated cAMP response elements ( $\mathrm{p}$ CREB), amyloid-beta (A $\beta)$, amyloid precursor protein (APP), p-tau, synapsin, and PSD-95 in mouse glial cells (41).

Carnosic acid (Compound 11) lowered the expression of NLRP3 and CASP1, along with myeloperoxidase (MPO) levels, in male $\mathrm{BALB} / \mathrm{c}$ mice. Additionally, it increased the level of nuclear factor erythroid 2 (Nrf2) and stopped the degradation of Nrf2 through a mechanism that involves impeding the interaction between Cullin3 and Keap1. It also increased the reduced glutathione (GSH) and superoxide dismutase (SOD) levels and caused a decrease in malondialdehyde (MDA) and iNOS levels in experimental animals (42). In wild-type C57BL/6 
and myristoylated alanine-rich C-kinase substrate (MARCKS) deficient mice, this diterpene has been found to suppress the PI3K/AKT, NLRP3/NF- $\mathrm{B}$, and sterol regulatory elementbinding protein 1 (SREBP-1c) signaling pathways (43). On the other hand, oridonin (Compound 12) exhibited an antiinflammatory effect in mice and HEK-293T cells, through the interaction with the cysteine 279 of NLRP3 in NACHT domain, thereby blocking the interaction between NLRP3 and NEK7 and inhibiting NLRP3 inflammasome formation and activation. Oridonin also reduced peritonitis, gouty arthritis, and type 2 diabetes in experimental animals by inhibiting NLRP3 activation (27). Similarly, teuvincenone F (Compound 13) attenuated the K63-linked ubiquitination of NF- $\mathrm{B}$-essential modulator inhibitor of nuclear factor kappa-B kinase gamma (IKK $\gamma)$ and inhibited the mRNA expression of IL-1 $\beta$, IL-6, IL-1 $\beta /$ IL-18, and TNF- $\alpha$ maturation in wild-type C57BL/6 mouse macrophages (44). However, a study by Huang et al. (26) suggested that phorbol 12-myristate 13-acetate induced human monocytic THP-1 cells and increased NLRP3 inflammasome expression by up-regulating the TLR4/MyD88/NF- $\mathrm{B}$ signaling pathway. In a similar fashion, paclitaxel caused mitochondrial damage and overproduction of ROS, along with activation of NLRP3 and neuropathic pain in male adult Sprague-Dawley rats (45). Listed in Table $\mathbf{1}$ are diterpenes and their derivatives' biological effects through NLRP3 inflammasome.

\section{DISCUSSION}

The NLRP3 is activated by many and diverse stimuli, making it the most versatile and important clinically implicated inflammasome. The intracellular NLRP3 receptor might be able to detect its levels through direct interactions, although it is reported that NLRP3 responds to certain generic cellular stress signals induced by the multitude of pathogen-associated molecular patterns (PAMPs) and damage-associated molecular patterns (DAMPs) that trigger its activation (49). The highmobility group box 1 (HMGB1) protein is also known for its activity, such as PAMP and DAMP components, which exaggerates immune stimulations at the time of tissue injury (50). Therefore, HMGB1 may be a potential therapeutic target in severe pulmonary inflammation, including coronavirus disease 2019 (Covid-19) caused by severe acute respiratory distress syndrome coronavirus 2 (SARS-CoV-2) (51). EOs are natural products with a complex composition. Terpenes are the most common class of chemical compounds present in EOs with diverse biological activities (52) and can be used as chemopreventive and therapeutic agents for treating various inflammatory diseases (53). Among terpenes, diterpenes and triterpenes are vastly studied due to their promising therapeutic benefits. Glycyrrhizin (also called glycyrrhizic acid), a triterpenoid saponin isolated, is used in Chinese Pharmacopeia (54). Recently, it has been demonstrated that this triterpene may be a hope in the Covid19 pandemic (55). Diterpenes are often with the molecular formula $\mathrm{C}_{20} \mathrm{H}_{32}$, which is composed of repeated isoprene subunits. Diterpenes and their derivatives are known for their antimicrobial and anti-inflammatory activities (14). In this study, it has been observed that diterpenes and their derivatives have interacted with NLRP3 in a variety of ways. For an example, andrographolide has been seen to reduce neuroinflammation in mouse glial cells through the HMGB1 pathway (39).

For the activation of pro-CASP1, research findings showed that caspase activation and recruitment domains (CARDs) act as a platform termed the ASC speck (56). Along this line, active CASP1 initiates the activation and release of IL-1 proteins (57), whereas the activation of NLRP3 causes the release of some pro-inflammatory mediators, including IL-1 $\beta$, IL-18, and highmobility group protein B1 (HMGB1) (58-60). Triptolide (30, $45,46)$, tanshinone IIA (31), phorbol myristate acetate (25), and teuvincenone $F(42)$ have been seen to reduce both IL- $1 \beta$ and IL18 expressions, whereas kaurenoic acid (35) and andrographolide (36-39) reduced the IL-1 $\beta$ expression in different test systems. Tanshinone IIA also attenuated ischemia/reperfusion injury (IRI) induced liver injury through down-regulating the HMGB1TLR-4/NF-кB pathway in Kupffer cells (KCs) and activated the PTEN/PI3K/AKT pathway (29).

NACHT, LRR, and PYD domains-containing protein 12 (NLRP12), a member of the NLRs, which is known to interact with the apoptosis-linked speck-like protein containing a CARD (ASC), cause the activation of CASP1, resulting in IL- $1 \beta$ release (61). Recently, it has been reported that the NLRP12, through its binding to the hematopoiesis cell kinase, may impart an effect on the pathogenesis of acute myeloid leukemia (62). Kaurenoic acid was seen to exert leishmanicidal activity through triggering a NLRP12/IL-1 $\beta /$ cNOS/NO pathway (35).

On the other hand, IKK $\gamma$ activates NF- $\kappa$ B. Furthermore, during the activation of NLRP3, transcription of the NLRP3 gene occurs, which activates NF- $\kappa \mathrm{B}$, including TLRs and TNF receptors $(18,63)$. In a recent study, triptolide was found to down-regulate hsa-miR-20b by targeting the NLRP3 gene in mice (33). Tanshinone IIA (34) and teuvincenone F (42) reduced TNF- $\alpha$ expression, whereas andrographolide was evident to down-regulate both NF- $\mathrm{B}$ and TNF- $\alpha$ expressions $(37-39,41)$. Additionally, teuvincenone $\mathrm{F}$ modulated the IKK $\gamma$ expression in mouse macrophages (42).

MyD88 was suggested to be responsible for NF- $\kappa$ B-dependent transcriptional priming (64). Triptolide (30), tanshinone IIA (34), and phorbol 12-myristate 13-acetate (43) were seen to act through this pathway. TLR4 stimulates NLRP3 inflammasome specific monocytes, which is alone sufficient to cause IL-1 $\beta$ and pro-IL-18 release (65). Triptolide (45), tanshinone IIA (34), phorbol 12-myristate 13-acetate (43), and andrographolide (39) were seen to act via this pathway. Moreover, p-CREB directly inhibits NF- $\mathrm{B}$ activation by a mechanism that involves hindering the binding of CREB-binding protein to the NF- $\kappa \mathrm{B}$ complex, thereby limiting pro-inflammatory responses and suggesting the induction of anti-apoptotic effect, along with proliferation and cell survival (66). Andrographolide was found to modulate the p-CREB expression in mouse glial cells (39). Therefore, the anti-inflammatory effects of the herbal contents and diterpenes $(26,28,44,67)$ may be related to their interaction potentials with NLRP3 by various pathways. 
TABLE 1 | Summary of bioactivities of diterpenes and/or their derivatives: test dose/conc., test system(s), and possible NLRP3 inflammasome and its associated mechanisms.

\begin{tabular}{|c|c|c|c|}
\hline $\begin{array}{l}\text { Diterpenes and/or their } \\
\text { derivatives }\end{array}$ & $\begin{array}{l}\text { Conc./dose (route of } \\
\text { administration)/test system }\end{array}$ & NLRP3 and NLRP3-associated action mechanism & References \\
\hline Phytanol, phytanyl amine & $\begin{array}{l}\text { Phytanol: } 40 \text { mg (i.p.) and phytanyl } \\
\text { amine: } 5 \text { mg (i.p.) in } \\
\text { immunoadjuvant effects in BALB/c } \\
\text { mice }\end{array}$ & $\begin{array}{l}\text { Immunostimulatory effect (decreases the expression of IL-6, MCP-1, KC, } \\
\text { MIP-1, LIX, BLC, T-cell activation-3 chemokines TCA, IL-4, IL-12, and } \\
\text { TIMP-1) }\end{array}$ & $(16)$ \\
\hline \multirow[t]{4}{*}{ Triptolide } & $\begin{array}{l}200 \mu \mathrm{g} / \mathrm{kg} / \text { day (i.g.) in female } \\
\text { Sprague-Dawley rats from } 12 \text { to } 28 \\
\text { weeks ( } n=15 \text { ) }\end{array}$ & $\begin{array}{l}\text { Anti-inflammatory effect (decreases the expression of IL-1 } \beta, I L-18, N L R P 3 \text {, } \\
\text { and TLR4) }\end{array}$ & $(45)$ \\
\hline & $\begin{array}{l}20 \text { or } 100 \mu \mathrm{g} / \mathrm{kg} / \text { day }(\mathrm{i} . \mathrm{p} .) \text { in } \\
\text { C57/BL6 mice (7-10) }\end{array}$ & $\begin{array}{l}\text { Cardio-protective effect (attenuates transverse aortic constriction-induced } \\
\text { myocardial remodeling and increases cardiac diastolic and systolic } \\
\text { functions, TGF- } \beta 1 \text { pathway, and pro-fibrotic genes. In a dose-dependent } \\
\text { manner, it additionally lowers NLRP3 inflammasome and downstream of } \\
\text { IL-1 } \beta \text {, IL-18, MCP-1, VCAM-1, and macrophage infiltration }\end{array}$ & $(46)$ \\
\hline & $\begin{array}{l}\text { In vivo: } 0.0035 \mathrm{mg} / \mathrm{ml} \text { (i.p.) in male } \\
\text { C57BL/6 mice }(n=5) \text { In vitro: } \\
20 \mathrm{ng} / \mathrm{ml} \text { in THP-1 cells }\end{array}$ & Prevention of osteoarthritis (decreases CASP1 and targeting hsa-miR-20b) & $(27)$ \\
\hline & $\begin{array}{l}10 \mu \mathrm{g} / \mathrm{ml} \text { in mouse cardiac } \\
\text { fibroblast cells }\end{array}$ & $\begin{array}{l}\text { Reduced IL-1 } \beta \text { maturation, MyD88-related phosphorylation of JNK, } \\
\text { ERK1/2, and TGF- } \beta 1 / \text { Smad signaling, thereby decreasing collagen } \\
\text { production, and inhibited NLRP3 expression and apoptosis-associated } \\
\text { speck-like proteins containing a caspase recruitment domain (ASC) }\end{array}$ & $(30)$ \\
\hline \multirow[t]{2}{*}{ Tanshinone IIA } & $\begin{array}{l}10 \text { mg/kg/day (i.p.) for } 1 \text { week in } \\
\text { male Sprague-Dawley rats }(n=15)\end{array}$ & $\begin{array}{l}\text { Hepatoprotective effect (decreases the expression of TNF- } \alpha \text {, IL-4, TLR-4, } \\
\text { MyD88, and p-NF-кB p65 and increases the phosphorylation of IL-10, } \\
\text { TGF- } \beta \text {, PTEN, PI3K, and AKT) }\end{array}$ & $(34)$ \\
\hline & $0-2.5 \mu \mathrm{g} / \mathrm{ml}$ in BV-2 cells & Protective effect (decreases NLRP3, CASP1, IL-1 $\beta$, and IL-18) & $(31)$ \\
\hline $\begin{array}{l}\text { Sodium tanshinone IIA } \\
\text { sulfonate }\end{array}$ & $\begin{array}{l}1.3,2.6 \text {, and } 5.2 \mathrm{mg} / \mathrm{kg}(\mathrm{i} . \mathrm{v} .) \text { in } \\
\text { Beagle dogs }(n=6)\end{array}$ & $\begin{array}{l}\text { Inhibition of myocardial inflammation and lipid accumulation (decreases } \\
\text { ROS and TXNIP up-expression through an impairment of the } \\
\text { JAK2-STAT3/insulin signaling/PPAR- } \alpha \text { pathway) }\end{array}$ & (33) \\
\hline \multirow[t]{2}{*}{ Paclitaxel } & $\begin{array}{l}0.5,1,5,10,50 \text {, and } 100 \mu \mathrm{g} / \mathrm{ml} \text { in } \\
\text { A549 cells }\end{array}$ & $\begin{array}{l}\text { Apoptotic cell death (decreases ROS-induced caspase-3 activation and } \\
\text { increases the ASK1/p38 MAPK signal pathway) }\end{array}$ & $(32)$ \\
\hline & $\begin{array}{l}2 \mathrm{mg} / \mathrm{kg} \text { (i.p.) for } 7 \text { days in male } \\
\text { adult Sprague-Dawley rats }\end{array}$ & $\begin{array}{l}\text { Neuropathic pain (increases mitochondrial damage and ROS production } \\
\text { and activates NLRP3 inflammasome) }\end{array}$ & $(44)$ \\
\hline $\begin{array}{l}\text { Kaurenoic acid } \\
\text { [ent-kaur-16-en-19-oic acid] }\end{array}$ & $\begin{array}{l}50,70, \text { and } 90 \mu \mathrm{M} \text { in Leishmania } \\
\text { amazonensis infected BALB/c mice }\end{array}$ & $\begin{array}{l}\text { Leishmanicidal activity (reestablishes the production of NO in a constitutive } \\
\text { NO synthase- (cNOS-) dependent fashion and increases the expression of } \\
\text { IL-1 } 1 \beta \text { and NLRP12) }\end{array}$ & (35) \\
\hline Phorbol myristate acetate & $\begin{array}{l}100 \mathrm{nM} \text { in mouse [BALB/cMlac } \\
\text { mice }(n=24)] \text { neutrophil cells }\end{array}$ & $\begin{array}{l}\text { Neuroprotective effect (decreases the mRNA expression of CASP1, IL-1 } \beta \text {, } \\
\text { IL-18, MCL1, and PYCARD) }\end{array}$ & $(25)$ \\
\hline $\begin{array}{l}\text { Phorbol 12-myristate } \\
\text { 13-acetate }\end{array}$ & Human monocytic THP-1 cells & $\begin{array}{l}\text { Inflammatory effect (increases the expression of the NLRP3 inflammasome } \\
\text { by up-regulation of the TLR4/MyD88/NF-кB signaling pathway) }\end{array}$ & $(43)$ \\
\hline \multirow[t]{4}{*}{ Andrographolide } & $\begin{array}{l}1 \mathrm{mg} / \mathrm{kg} \text { (p.o.), 3-times/week) in } \\
\text { mice ( } \mathrm{n}=7-10) \text { and } 20 \text { and } 50 \mathrm{M} \text { in } \\
\text { HepG2 cells }\end{array}$ & $\begin{array}{l}\text { Hepatoprotective effect (decreases inflammation, fibrosis, hepatic } \\
\text { macrophage infiltration, hepatic mRNA levels of both pro-inflammatory and } \\
\text { pro-fibrotic genes, expression of inflammasome genes, IL-1 } 1 \beta \text { expression } \\
\text { through the NF-кB inhibitory pathway, and inflammasome disassembly) }\end{array}$ & (38) \\
\hline & $\begin{array}{l}\text { In vivo: } 5 \text { and } 10 \mathrm{mg} / \mathrm{kg} \text { (i.p. for } \\
\text { 10-14 days) in OVA-induced female } \\
\text { C57/BL6 mice ( } n=8) \\
\text { In vitro: } 30 \mu \mathrm{M} \text { in OVA-induced } \\
\text { BMDM cells }\end{array}$ & $\begin{array}{l}\text { Inhibition of lung injury (decreases the expression of TNF- } \alpha, \mathrm{IL}-1 \beta \text {, and } \\
\text { ROS-mediated NF-кB) }\end{array}$ & $(37)$ \\
\hline & $1 \mu \mathrm{g} / \mathrm{ml}$ in mouse glial cells & $\begin{array}{l}\text { Neuropharmacological effect (decreases HMGB1, TLR4, NF-кB, COX-2, } \\
\text { iNOS, MIP-1 } \alpha, \text { P2X7, CASP1, and mature IL-1 } \beta \text { and modulates the } \\
\text { expression of protein markers, such as PKC, p-CREB, amyloid-beta, APP, } \\
\text { p-tau, synapsin, and PSD-95) }\end{array}$ & (39) \\
\hline & 7.5 and 15 mg/kg (i.g.) mice $(n=6)$ & $\begin{array}{l}\text { Anti-colitis and anti-tumor effect (decrease the expression of cleaved } \\
\text { CASP1, IL-I } 3 \text {, mitochondrial membrane potential collapse, and } \\
\text { PI3KCA-AKT1-mTOR-RPS6KB1 pathway; increases the disruption of } \\
\text { NLRP3-PYCARD-CASP1 complex assembly and mitophagy in } \\
\text { macrophages; inactivates the NLRP3 inflammasome; and induces } \\
\text { autophagy) }\end{array}$ & $(36)$ \\
\hline
\end{tabular}


TABLE 1 | Continued

\begin{tabular}{|c|c|c|c|}
\hline $\begin{array}{l}\text { Diterpenes and/or their } \\
\text { derivatives }\end{array}$ & $\begin{array}{l}\text { Conc./dose (route of } \\
\text { administration)/test system }\end{array}$ & NLRP3 and NLRP3-associated action mechanism & References \\
\hline \multirow[t]{2}{*}{ Carnosic acid } & $\begin{array}{l}50 \text { and } 100 \mathrm{mg} / \mathrm{kg}(\text { p.o. }) \text { for } 3 \text { days } \\
\text { in male BALB/c mice }(\mathrm{n}=8)\end{array}$ & $\begin{array}{l}\text { Inhibition of acute colitis (decreases CASP1 expression and MPO, MDA, } \\
\text { and iNOS levels; increases Nrf2 expression; prevents the degradation of } \\
\text { Nrf2 via ubiquitination by blocking the interaction between Cullin3 and } \\
\text { Keap1; and increases GSH and SOD levels) }\end{array}$ & $(40)$ \\
\hline & $\begin{array}{l}30 \mathrm{mg} / \mathrm{kg} \text { (i.g.) in male wild-type } \\
\text { C57BL/6 and MARCKS deficient } \\
\text { mice }(\mathrm{n}=15)\end{array}$ & $\begin{array}{l}\text { Non-alcoholic fatty liver disease (decreases PI3K/AKT, NLRP3/NF-KB, and } \\
\text { SREBP-1c signaling pathways) }\end{array}$ & $(41)$ \\
\hline Oridonin & $\begin{array}{l}3 \text { or } 20 \mathrm{mg} / \mathrm{kg} \text { (i.p.) once a day for } 6 \\
\text { weeks in C57BL/6J and WT or } \\
\text { NIrp3 }{ }^{-/-} \text {mice }(n=6) ; 0.1-2 \mu \mathrm{M} \text { in } \\
\text { HEK-293T cells }\end{array}$ & $\begin{array}{l}\text { Anti-inflammatory effect (increases the interaction with cysteine } 279 \text { of } \\
\text { NLRP3 in NACHT domain; blocks the interaction between NLRP3 and } \\
\text { NEK7; inhibits NLRP3 inflammasome assembly and activation; reduces } \\
\text { peritonitis, gouty arthritis, and type } 2 \text { diabetes; and inhibits NLRP3 } \\
\text { activation) }\end{array}$ & $(24)$ \\
\hline Teuvincenone $\mathrm{F}$ & $\begin{array}{l}6.25,12.25 \text {, and } 25 \mu \mathrm{M} \text { in wild-type } \\
\text { C57BL/6 mouse macrophages }\end{array}$ & $\begin{array}{l}\text { Anti-inflammatory effect (decreases the K63-linked ubiquitination of } \\
\text { NF-kB-essential modulator IKK } \gamma \text { and mRNA expression of IL-1 } \beta \text {, IL-6, } \\
\text { TNF- } \alpha \text {, and IL-1 } \beta / I L-18 \text { maturation) }\end{array}$ & $(42)$ \\
\hline $\begin{array}{l}\text { Heartwood of Taiwan fir } \\
\text { (diterpene content } 0.9 \% \text { ) }\end{array}$ & LPS-activated macrophages & $\begin{array}{l}\text { Anti-inflammatory effect (decreases NLRP3 inflammasome-derived IL-I } \beta \\
\text { secretion induced by LPS and ATP) }\end{array}$ & $(47)$ \\
\hline Geranylgeraniol & $50 \mu \mathrm{M}$ in a neuronal cell line (Daoy) & $\begin{array}{l}\text { Neurological impairment (decreases NLRP3 gene expression and } \\
\text { mitochondrial dysfunction-linked programmed cell death) }\end{array}$ & $(48)$ \\
\hline
\end{tabular}

In the meantime, sterol regulatory element-binding proteins (SREBPs) are known to regulate lipid homeostasis and activate the transcription of genes encoding enzymes involved in the biosynthesis of compounds including cholesterol, triglycerides, phospholipids, and fatty acids. In this regard, SREBP-1c, one of the three SREBP isoforms, activates genes that are involved in fatty acid synthesis (68); this isoform can be activated by an AKTdependent pathway (69). Similarly, research findings indicated that NLRP3 inflammasome complex/CASP1 triggers SREBP and promotes membrane biogenesis, resulting in host cell survival in response to some toxins (70). In addition, the hepatoprotective effect of tanshinone IIA (29) may be related to the inhibitory capacity of the NLRP3 inflammasome-induced inflammation cascade pathway, whereas for carnosic acid (43), it might be due to the inhibition capacity of SREBP-1c signaling pathways.

The opening of the P2X7 channel may lead to the accumulation of high levels of extracellular ATP (71) when there are dying cells in the vicinity of inflammasome-containing cells. Furthermore, aggregation of islet amyloid polypeptide (IAPP), a hormone secreted by $\beta$ cells and $A \beta$ plaques, may cause interaction with phosphorylated tau ( $\mathrm{p}$-tau) and damage to the neuronal structure and function, particularly synapses; this can lead to a cognitive decline in Alzheimer's patients (7274). Andrographolide reduced P2X7, whereas it modulated p-tau expression in mouse glial cells (39). Moreover, mitochondrial dysfunction and production of mtROS are considered vital for the activation of NLRP3 inflammasome (75), whereas subsequent activation of STAT3 limits NLRP3 inflammasome priming (76). Interleukins from IL-12 family, such as IL-27, may enhance the LPS response in monocytes, in a STAT3NF-кB-dependent manner through the up-regulation of TLR4 expression (77). Sodium tanshinone IIA sulfonate decreased ROS and TXNIP overexpression through an impairment of the JAK2STAT3/insulin signaling/PPAR- $\alpha$ pathway (33).

The nuclear factor E2-related factor 2 (Nrf2) plays a regulatory role in the NLRP3 inflammasome. Nrf2 constantly degrades upon ubiquitination under normal conditions. These inflammasomes represent stress-induced protein complexes that are involved in acute and chronic inflammation by means of CASP1-mediated activation of pro-inflammatory cytokines (78). Carnosic acid increased Nrf2 expression and prevents the degradation of Nrf2 via ubiquitination by blocking the interaction between Cullin3 and Keap1 (40). In addition, intragraft KC expression, associated with NLRP3 inflammasomes, can be considered as a new therapeutic strategy in the treatment of liver graft injury (34). Moreover, PPARs, especially the $\operatorname{PPAR} \alpha$, are needed to prevent excessive inflammatory responses, as it controls the inflammasome complex NLRP3 activation (79). TXNIP translocates to the mitochondria, along with NLRP3, and causes activation of the inflammasome, which is also responsible for endoplasmic reticulum (ER) stress in animals (80). Sodium tanshinone IIA sulfonate inhibited myocardial inflammation and lipid accumulation via decreasing TXNIP upexpression through an impairment of the JAK2-STAT3/insulin signaling/PPAR- $\alpha$ pathway (33). In this regard, the PI3KAKT pathway is responsible for the ER-mediated $\mathrm{Ca}^{2+}$ release (81). The voltage-dependent anion channel is involved in the transport of $\mathrm{Ca}^{2+}$ to the mitochondria, which accelerates ROS production and inflammasome activation (82). Tanshinone IIA (34), andrographolide (36), and carnosic acid (41) were seen to act through the PI3K-AKT-dependent pathway. Recent research findings indicated that inflammasome-independent NLRP3 enhances TGF- $\beta 1$ signaling in certain tissues, including kidney epithelium and cardiac fibroblasts $(83,84)$. Tanshinone IIA 
increased TGF- $\beta 1$ expression (34), whereas triptolide reduced TGF- $\beta 1 /$ Smad signaling (30) in experimental animals.

In primary human macrophages, p38 $\delta$ MAPK has been recognized as a regulator of NLRP3 inflammasome activation, which might be one of the potential targets for the treatment of atherosclerotic inflammation (85). On the other hand, TIMP1 is a glycoprotein expressed in several tissues in our body. TIMP-1 plays a role in wound healing (86) and pregnancy (87). The dysregulated activity of TIMP- 1 is found to be associated with cancer (88), and NLRP3 can down-regulate TIMP-1 (89). Phytanol and phytanyl amine exerted an immunostimulatory effect through decreasing the expression of TIMP-1 in a mouse model (16). A recent review by Mangan et al. (12) has been published, with a focus on NLRP3 inflammasome biology, activation pathways, and its roles in mammalian pathophysiology, current drug target, and future aspects. Taken all together, it is widely accepted that diterpenes have diverse biological responses in various test systems via interaction with the NLRP3 inflammasome.

Benzodiazepines (e.g., DZP) are positive allosteric modulators of the neurotransmitter gamma-aminobutyric acid $\left(\mathrm{GABA}_{\mathrm{A}}\right)$ receptor. GABA, the major inhibitory neurotransmitter in the brain, after binding to benzodiazepines, increases the total conduction of chloride ions across the neuronal cell membrane and causes chloride ion influx, hyperpolarizing the neuron's membrane potential. Therefore, the difference between resting potential and threshold potential is increased, and firing is less likely. As a result, arousal of the cortical and limbic systems in the central nervous system is reduced (25). To exert an anxiolytic effect, DZP appears to act on areas of the limbic system, thalamus, and hypothalamus. Plant-derived compounds, including terpenes and terpenoids, possess anxiolytic effects in a wide range of animal models of anxiety (35). In fact, diterpenes are a promising source of neurological agents (90).

The recent human threat SARS-CoV-2 is known to produce cytokine storm in Covid-19 patients. It is evident to release pro-inflammatory cytokines, including IL- 6 and IL- $1 \beta$ through

\section{REFERENCES}

1. Pushpangadan P, Ijinu T, George V. Plant based anti-inflammatory secondary metabolites. Ann Phytomed. (2015) 4:17-36.

2. Kunnas T, Määttä K, Nikkari ST. NLR family pyrin domain containing 3 (NLRP3) inflammasome gene polymorphism rs7512998 (C> T) predicts aging-related increase of blood pressure, the TAMRISK study. Immun Ageing. (2015) 12:19. doi: 10.1186/s12979-015-0047-7

3. Turunen JA, Wedenoja J, Repo P, Järvinen R-S, Jäntti JE, Mörtenhumer S, et al. Keratoendotheliitis Fugax Hereditaria: a novel cryopyrin-associated periodic syndrome caused by a mutation in the nucleotide-binding domain, Leucine-Rich repeat family, Pyrin Domain-Containing 3. (NLRP3) gene. Am J Ophthalmol. (2018) 188:41-50. doi: 10.1016/j.ajo.2018.01.017

4. Church LD, Cook GP, Mcdermott MF. Primer: inflammasomes and interleukin $1 \beta$ in inflammatory disorders. Nat Clin Pract Rheumatol. (2008) 4:34-42. doi: 10.1038/ncprheum0681

5. Martinon F. Detection of immune danger signals by NALP3. J Leukocyte Biol. (2008) 83:507-11. doi: 10.1189/jlb.0607362

6. Levy M, Thaiss CA, Elinav E. Taming the inflammasome. Nat Med. (2015) 21:213. doi: $10.1038 / \mathrm{nm} .3808$ the NLRP3 inflammasome pathway (91). Many natural products and their derivatives, including diterpenes, have been found to act against human coronaviruses, such as SARS-CoV and the Middle East respiratory syndrome-related coronavirus (MERS$\mathrm{CoV})(92,93)$. Therefore, diterpenes and their derivatives acting through the NLRP3 inflammasome pathway might be a new hope to fight against the current pandemic outbreak.

\section{CONCLUSIONS}

At the present time, the utilization of natural products and their derivatives has gained popularity due to the lesser side effects and economy as compared with other treatment strategies. Cumulative research papers have dealt with the health-promoting benefits of diterpenes and their derivatives as they could be used as chemotherapeutic tools against many diseases, including cancer, diabetes, obesity, and neurological diseases and disorders. Findings from this review highlight the role of diterpenes and their interaction with the NLRP3 inflammasome. In addition, this review has shown that NLRP3 inflammasome can be an important molecular platform in the induction of the central pro-inflammatory cytokine IL-1 $\beta$ via the activation of CASP1. The NLRP3 inflammasome is able to act through the mitochondria; therefore, it has an important impact on physiological homeostasis and metabolic balance. Furthermore, this review has shed some light on 13 important diterpenes that act through the NLRP3 inflammasome interactive pathway, providing new insights for the development of new therapeutic modalities.

\section{AUTHOR CONTRIBUTIONS}

MI and JS-R: conceptualization. SB: validation investigation. MI, SB, MM, WK, KG-B, BA, and JS-R: resources. MI, SB, and MM: data curation. MI, JS-R, and WK: review and editing. All the authors writing, read, and approved the final manuscript. All authors contributed equally to the manuscript.

7. Liu-Bryan R. Intracellular innate immunity in gouty arthritis: role of NALP3 inflammasome. Immunol Cell Biol. (2010) 88:20-3. doi: 10.1038/icb.2009.93

8. Heneka MT, Kummer MP, Stutz A, Delekate A, Schwartz S, Vieira-Saecker A, et al. NLRP3 is activated in Alzheimer's disease and contributes to pathology in APP/PS1 mice. Nature. (2013) 493:674-8. doi: 10.1038/nature11729

9. Shi F, Kouadir M, Yang Y. NALP3 inflammasome activation in protein misfolding diseases. Life Sci. (2015) 135:9-14. doi: 10.1016/j.lfs.2015.05.011

10. Fan S-H, Wang Y-Y, Lu J, Zheng Y-L, Wu D-M, Li M-Q, et al. Luteoloside suppresses proliferation and metastasis of hepatocellular carcinoma cells by inhibition of NLRP3 inflammasome. PLOS ONE. (2014) 9:89961. doi: 10.1371/journal.pone.0089961

11. Wei Q, Mu K, Li T, Zhang Y, Yang Z, Jia X, et al. Deregulation of the NLRP3 inflammasome in hepatic parenchymal cells during liver cancer progression. Lab Invest. (2014) 94:52-62. doi: 10.1038/labinvest.2013.126

12. Mangan MS, Olhava EJ, Roush WR, Seidel HM, Glick GD, Latz E. Targeting the NLRP3 inflammasome in inflammatory diseases. Nat Rev Drug Discov. (2018) 17:588. doi: 10.1038/nrd.2018.97

13. Korkina L, Kostyuk V, De Luca C, Pastore S. Plant phenylpropanoids as emerging anti-inflammatory agents. Mini Rev Med Chem. (2011) 11:823-35. doi: $10.2174 / 138955711796575489$ 
14. Islam MT, Da Mata AMOF, De Aguiar RPS, Paz MFCJ, De Alencar MVOB, Ferreira PMP, et al. Therapeutic potential of essential oils focusing on diterpenes. Phytother Res. (2016) 30:1420-44. doi: 10.1002/ptr.5652

15. Tan WD, Liao W, Zhou S, Wong WF. Is there a future for andrographolide to be an anti-inflammatory drug? Deciphering its major mechanisms of action. Biochem Pharmacol. (2017) 139:71-81. doi: 10.1016/j.bcp.2017.03.024

16. Hao D-C, Ge G-B, Xiao P-G. Anticancer drug targets of Salvia phytometabolites: chemistry, Biology and omics. Curr Drug Targets. (2018) 19:1-20. doi: 10.2174/1389450117666161207141020

17. Tricarico PM, Kleiner G, Valencic E, Campisciano G, Girardelli M, Crovella $\mathrm{S}$, et al. Block of the mevalonate pathway triggers oxidative and inflammatory molecular mechanisms modulated by exogenous isoprenoid compounds. Int J Mol Sci. (2014) 15:6843-56. doi: 10.3390/ijms 15046843

18. Bauernfeind FG, Horvath G, Stutz A, Alnemri ES, Macdonald K, Speert $\mathrm{D}$, et al. Cutting edge: NF- $\mathrm{KB}$ activating pattern recognition and cytokine receptors license NLRP3 inflammasome activation by regulating NLRP3 expression. J Immunol. (2009) 183:787-91. doi: 10.4049/jimmunol.0901363

19. Gurung P, Anand PK, Malireddi RKS, Walle LV, Opdenbosch NV, Dillon CP, et al. FADD and caspase- 8 mediate priming and activation of the canonical and noncanonical Nlrp3 inflammasomes. J Immunol. (2014) 192:1835-46. doi: 10.4049/jimmunol.1302839

20. Song N, Liu ZS, Xue W, Bai ZF, Wang QY, Dai J, et al. NLRP3 phosphorylation is an essential priming event for inflammasome activation. Mol Cell. (2017) 68:185-97. doi: 10.1016/j.molcel.2017.08.017

21. Dostert C, Pétrilli V, Bruggen RV, Steele C, Mossman BT, Tschopp J. Innate immune activation through Nalp3 inflammasome sensing of asbestos and silica. Science. (2008) 320:674-7. doi: 10.1126/science.1156995

22. Muñoz-Planillo R, Kuffa P, Martínez-Colón G, Smith BL, Rajendiran TM, Núñez G. $\mathrm{K}^{+}$efflux is the common trigger of NLRP3 inflammasome activation by bacterial toxins and particulate matter. Immunity. (2013) 38:1142-53. doi: 10.1016/j.immuni.2013.05.016

23. He Y, Franchi L, Núñez G. TLR agonists stimulate Nlrp3-dependent IL-1 $\beta$ production independently of the purinergic $\mathrm{P} 2 \mathrm{X} 7$ receptor in dendritic cells and in vivo. J Immunol. (2013) 190:334-9. doi: 10.4049/jimmunol.1202737

24. Aachoui Y, Chowdhury RR, Fitch RW, Ghosh SK. Molecular signatures of phytol-derived immunostimulants in the context of chemokine-cytokine microenvironment and enhanced immune response. Cell Immunol. (2011) 271:227-38. doi: 10.1016/j.cellimm.2011.07.001

25. Liu W, Gu J, Qi J, Zeng XN, Ji J, Chen ZZ, et al. Lentinan exerts synergistic apoptotic effects with paclitaxel in A549 cells via activating ROS-TXNIP-NLRP 3 inflammasome. J Cell Mol Med. (2015) 19:1949-55. doi: $10.1111 / \mathrm{jcmm} .12570$

26. Huang Z, Ye B, Han J, Kong F, Shan P, Lu Z, et al. NACHT, LRR and PYD domains-containing protein 3 inflammasome is activated and inhibited by berberine via toll-like receptor 4/myeloid differentiation primary response gene 88 /nuclear factor- $\kappa B$ pathway, in phorbol 12myristate 13-acetate-induced macrophages. Mol Med Rep. (2018) 17:2673-80. doi: $10.3892 / \mathrm{mmr} .2017 .8189$

27. He $\mathrm{H}$, Jiang $\mathrm{H}$, Chen $\mathrm{Y}$, Ye J, Wang $\mathrm{A}$, Wang $\mathrm{C}$, et al. Oridonin is a covalent NLRP3 inhibitor with strong anti-inflammasome activity. Nat Commun. (2018) 9:2550. doi: 10.1038/s41467-018-04947-6

28. He L, Peng X, Liu G, Tang C, Liu H, Liu F, et al. Anti-inflammatory effects of triptolide on IgA nephropathy in rats. Immunopharmacology and immunotoxicology. (2015) 37:421-7. doi: 10.3109/08923973.2015.1080265

29. Li X, Wu Y, Zhang W, Gong J, Cheng Y. Pre-conditioning with tanshinone IIA attenuates the ischemia/reperfusion injury caused by liver grafts via regulation of HMGB1 in rat Kupffer cells. Biomed Pharmacother. (2017) 89:1392-400. doi: 10.1016/j.biopha.2017.03.022

30. Pan XC, Liu Y, Cen YY, Xiong YL, Li JM, Ding YY, et al. Dual role of triptolide in interrupting the NLRP3 inflammasome pathway to attenuate cardiac fibrosis. Int J Mol Sci. (2019) 20:360. doi: 10.3390/ijms20020360

31. Qian K, Zhang L, Shi K. Triptolide prevents osteoarthritis via inhibiting hsa-miR-20b. Inflammopharmacology. (2019) 27:109-19. doi: 10.1007/s10787-018-0509-6

32. Cai L, Yi X, Yuan L, Gong G. The protective effect of tanshinone IIA on oxygen-glucose deprivation and reperfusion injury of microgliathrough the NLRP3 inflammatory signaling pathway. J Sichuan University Med Sci
Edn. (2016) 47:660-4. Available online at: https://pubmed.ncbi.nlm.nih.gov/ 28598075/

33. Li R, Lu K, Wang Y, Chen M, Zhang F, Shen H, et al. Triptolide attenuates pressure overload-induced myocardial remodeling in mice via the inhibition of NLRP3 inflammasome expression. Biochem Biophys Res Commun. (2017) 485:69-75. doi: 10.1016/j.bbrc.2017.02.021

34. Hu Q, Wei B, Wei L, Hua K, Yu X, Li H, et al. Sodium tanshinone IIA sulfonate ameliorates ischemia-induced myocardial inflammation and lipid accumulation in Beagle dogs through NLRP3 inflammasome. Int J Cardiol. (2015) 196:183-92. doi: 10.1016/j.ijcard.2015.05.152

35. Miranda MM, Panis C, da Silva SS, Macri JA, Kawakami NY, Hayashida $\mathrm{TH}$, et al. Kaurenoic acid possesses leishmanicidal activity by triggering a NLRP12/IL-1 $\beta / c N O S / N O$ Pathway. Med Inflam. (2015) 2015:392918. doi: $10.1155 / 2015 / 392918$

36. Luehong N, Khaowmek J, Wongsawan K, Chuammitri P. Preferential pattern of mouse neutrophil cell death in response to various stimulants. In vitro Cell Dev Biol Animal. (2017) 53:513-24. doi: 10.1007/s11626-016-0129-7

37. Marcuzzi A, Piscianz E, Zweyer M, Bortul R, Loganes C, Girardelli $\mathrm{M}$, et al. Geranylgeraniol and neurological impairment: involvement of apoptosis and mitochondrial morphology. Int J Mol Sci. (2016) 17:365. doi: $10.3390 /$ ijms 17030365

38. Guo W, Sun Y, Liu W, Wu X, Guo L, Cai P, et al. Small molecule-driven mitophagy-mediated NLRP3 inflammasome inhibition is responsible for the prevention of colitis-associated cancer. Autophagy. (2014) 10:972-85. doi: 10.4161 /auto. 28374

39. Peng S, Gao J, Liu W, Jiang C, Yang X, Sun Y, et al. Andrographolide ameliorates OVA-induced lung injury in mice by suppressing ROS-mediated NF-KB signaling and NLRP3 inflammasome activation. Oncotarget. (2016) 7:80262. doi: $10.18632 /$ oncotarget. 12918

40. Cabrera D, Wree A, Povero D, Solís N, Hernandez A, Pizarro M, et al. Andrographolide ameliorates inflammation and fibrogenesis and attenuates inflammasome activation in experimental non-alcoholic steatohepatitis. Sci Rep. (2017) 7:3491. doi: 10.1038/s41598-017-03675-z

41. Das S, Mishra K, Ganju L, Singh S. Andrographolide-A promising therapeutic agent, negatively regulates glial cell derived neurodegeneration of prefrontal cortex, hippocampus and working memory impairment. J Neuroimmunol. (2017) 313:161-75. doi: 10.1016/j.jneuroim.2017.11.003

42. Yang N, Xia Z, Shao N, Li B, Xue L, Peng Y, et al. Carnosic acid prevents dextran sulfate sodium-induced acute colitis associated with the regulation of the Keap1/Nrf2 pathway. Sci Rep. (2017) 7:1-12. doi: 10.1038/s41598-017-11408-5

43. Song H-M, Li X, Liu Y-Y, Lu W-P, Cui Z-H, Zhou L, et al. Carnosic acid protects mice from high-fat diet-induced NAFLD by regulating MARCKS. Int J Mol Med. (2018) 42:193-207. doi: 10.3892/ijmm.20 18.3593

44. Zhao X, Pu D, Zhao Z, Zhu H, Li H, Shen Y, et al. Teuvincenone F suppresses LPS-induced inflammation and NLRP3 inflammasome activation by attenuating NEMO ubiquitination. Front Pharmacol. (2017) 8:565. doi: $10.3389 /$ fphar.2017.00565

45. Jia M, Wu C, Gao F, Xiang H, Sun N, Peng P, et al. Activation of NLRP3 inflammasome in peripheral nerve contributes to paclitaxelinduced neuropathic pain. Mol Pain. (2017) 13:1744806917719804. doi: 10.1177/1744806917719804

46. Liu $\mathrm{H}$, Lo $\mathrm{CM}$, Yeung OWH, Li CX, Liu XB, Qi X, et al. NLRP3 inflammasome induced liver graft injury through activation of telomereindependent RAP1/KC axis. J Pathol. (2017) 242:284-96. doi: 10.1002/ path. 4901

47. Huang $\mathrm{Y}$, Jiang $\mathrm{H}$, Chen $\mathrm{Y}$, Wang $\mathrm{X}$, Yang $\mathrm{Y}$, Tao J, et al. Tranilast directly targets NLRP3 to treat inflammasome-driven diseases. EMBO Mol Med. (2018) 10. doi: 10.15252/emmm.201708689

48. Lim MM, Szymusiak R. Neurobiology of arousal and sleep: updates and insights into neurological disorders. Cur Sleep Med Rep. (2015) 1:91-100. doi: 10.1007/s40675-015-0013-0

49. Abderrazak A, Syrovets T, Couchie D, El Hadri K, Friguet B, Simmet T, et al. NLRP3 inflammasome: from a danger signal sensor to a regulatory node of oxidative stress and inflammatory diseases. Redox Biol. (2015) 4:296-307. doi: 10.1016/j.redox.2015.01.008 
50. Avgousti DC, Herrmann C, Kulej K, Pancholi NJ, Sekulic N, Petrescu J, et al. A core viral protein binds host nucleosomes to sequester immune danger signals. Nature. (2016) 535:173-7. doi: 10.1038/nature18317

51. Andersson U, Ottestad W, Tracey KJ. Extracellular HMGB1: a therapeutic target in severe pulmonary inflammation including COVID-19? Mol Med. (2020) 26:42. doi: 10.1186/s10020-020-00172-4

52. de Matos SP, Teixeira HF, de Lima ÁAN, Veiga-Junior VF, Koester LS. Essential oils and isolated terpenes in nanosystems designed for topical administration: a review. Biomolecules. (2019) 9:138. doi: 10.3390/biom 9040138

53. Kim T, Song B, Cho KS, Lee IS. Therapeutic potential of volatile terpenes and terpenoids from forests for inflammatory diseases. Int J Mol Sci. (2020) 21:2187. doi: 10.3390/ijms21062187

54. Chen L, Hu C, Hood M, Zhang X, Zhang L, Kan J, et al. A novel combination of vitamin $\mathrm{C}$, curcumin and glycyrrhizic acid potentially regulates immune and inflammatory response associated with coronavirus infections: a perspective from system biology analysis. Nutrients. (2020) 12:1193. doi: 10.3390/nu12041193

55. Bailly C, Vergoten G. Glycyrrhizin: an alternative drug for the treatment of COVID-19 infection and the associated respiratory syndrome? Pharmacol Therapeut. (2020) 214:107618. doi: 10.1016/j.pharmthera.2020.107618

56. Hoss F, Rodriguez-Alcazar JF, Latz E. Assembly and regulation of ASC specks. Cell Mol Life Sci. (2017) 74:1211-29. doi: 10.1007/s00018-016-2396-6

57. Keller M, Rüegg A, Werner S, Beer H-D. Active caspase-1 is a regulator of unconventional protein secretion. Cell. (2008) 132:818-31. doi: 10.1016/j.cell.2007.12.040

58. Kanneganti T-D, Özören N, Body-Malapel M, Amer A, Park J-H, Franchi L, et al. Bacterial RNA and small antiviral compounds activate caspase- 1 through cryopyrin/Nalp3. Nature. (2006) 440:233-6. doi: 10.1038/nature04517

59. Willingham SB, Allen IC, Bergstralh DT, Brickey WJ, Huang MT-H, Taxman DJ, et al. NLRP3. (NALP3, Cryopyrin) facilitates in vivo caspase-1 activation, necrosis, and HMGB1 release via inflammasome-dependent and-independent pathways. J Immunol. (2009) 183:2008-15. doi: 10.4049/jimmunol.0900138

60. Von Moltke J, Trinidad NJ, Moayeri M, Kintzer AF, Wang SB, Van Rooijen N, et al. Rapid induction of inflammatory lipid mediators by the inflammasome in vivo. Nature. (2012) 490:107-11. doi: 10.1038/nature11351

61. Wang L, Manji GA, Grenier JM, Al-Garawi A, Merriam S, Lora JM, et al. PYPAF7, a novel PYRIN-containing Apaf1-like protein that regulates activation of NF- $\mathrm{BB}$ and caspase-1-dependent cytokine processing. J Biol Chem. (2002) 277:29874-80. doi: 10.1074/jbc.M203915200

62. Zhang Y, Okamoto CT. Nucleotide binding domain and leucine-rich repeat pyrin domain-containing protein 12: characterization of its binding to hematopoietic cell kinase. Int J Biol Sci. (2020) 16:1507-25. doi: $10.7150 /$ ijbs. 41798

63. Franchi L, Eigenbrod T, Núñez G. Cutting edge: TNF- $\alpha$ mediates sensitization to ATP and silica via the NLRP3 inflammasome in the absence of microbial stimulation. J Immunol. (2009) 183:792-6. doi: 10.4049/jimmunol.0900173

64. Sutterwala FS, Haasken S, Cassel SL. Mechanism of NLRP3 inflammasome activation. Annals N Y Acad Sci. (2014) 1319:82. doi: 10.1111/nyas.12458

65. Osawa R, Williams KL, Singh N. The inflammasome regulatory pathway and infections: role in pathophysiology and clinical implications. J Infect. (2011) 62:119-29. doi: 10.1016/j.jinf.2010.10.002

66. Wen AY, Sakamoto KM, Miller LS. The role of the transcription factor CREB in immune function. J Immunol. (2010) 185:6413-9. doi: 10.4049/jimmunol.1001829

67. Liu ML, Hua KF, Yang TJ, Chiu HW, Ho CL. Essential oil from the heartwood of taiwan fir ameliorates LPS-induced inflammatory response by inhibiting the activation of mitogen-activated protein kinase. Nat Product Commun. (2014) 9:1934578X1400901029. doi: 10.1177/1934578X1400901029

68. Brown MS, Goldstein JL. A proteolytic pathway that controls the cholesterol content of membranes, cells, and blood. Proc Natl Acad Sci USA. (1999) 96:11041-8. doi: 10.1073/pnas.96.20.11041

69. Park C-Y, Jun H-J, Wakita T, Cheong JH, Hwang SB. Hepatitis C virus nonstructural $4 \mathrm{~B}$ protein modulates sterol regulatory element-binding protein signaling via the AKT pathway. J Biol Chem. (2009) 284:9237-46. doi: 10.1074/jbc.M808773200

70. Gurcel L, Abrami L, Girardin S, Tschopp J, Van Der Goot FG. Caspase-1 activation of lipid metabolic pathways in response to bacterial pore-forming toxins promotes cell survival. Cell. (2006) 126:1135-45. doi: 10.1016/j.cell.2006.07.033

71. Próchnicki T, Mangan MS, Latz E. Recent insights into the molecular mechanisms of the NLRP3 inflammasome activation. F1000Research. (2016) 5:F1000. doi: 10.12688/f1000research.8614.1

72. Halle A, Hornung V, Petzold GC, Stewart CR, Monks BG, Reinheckel T, et al. The NALP3 inflammasome is involved in the innate immune response to amyloid- $\beta$. Nat Immunol. (2008) 9:857. doi: 10.1038/ni.1636

73. Masters SL, Dunne A, Subramanian SL, Hull RL, Tannahill GM, Sharp FA, et al. Activation of the NLRP3 inflammasome by islet amyloid polypeptide provides a mechanism for enhanced IL-1 $\beta$ in type 2 diabetes. Nat Immunol. (2010) 11:897. doi: 10.1038/ni.1935

74. Manczak M, Reddy PH. Abnormal interaction of oligomeric amyloid- $\beta$ with phosphorylated tau: implications to synaptic dysfunction and neuronal damage. J Alzheimer's Dis. (2013) 36:285-95. doi: 10.3233/JAD-130275

75. Abais JM, Xia M, Zhang Y, Boini KM, Li P-L. Redox regulation of NLRP3 inflammasomes: ROS as trigger or effector? Antioxidants Redox Signal. (2015) 22:1111-29. doi: 10.1089/ars.2014.5994

76. Guarda G, Braun M, Staehli F, Tardivel A, Mattmann C, Förster I, et al. Type I interferon inhibits interleukin-1 production and inflammasome activation. Immunity. (2011) 34:213-23. doi: 10.1016/j.immuni.2011.02.006

77. Guzzo C, Ayer A, Basta S, Banfield BW, Gee K. IL-27 enhances LPSinduced proinflammatory cytokine production via upregulation of TLR4 expression and signaling in human monocytes. J Immunol. (2012) 188:864-73. doi: 10.4049/jimmunol.1101912

78. Garstkiewicz M, Strittmatter GE, Grossi S, Sand J, Fenini G, Werner S, et al. Opposing effects of Nrf2 and Nrf2-activating compounds on the NLRP3 inflammasome independent of Nrf2-mediated gene expression. Eur J Immunol. (2017) 47:806-17. doi: 10.1002/eji.201646665

79. Gugliandolo E, Fusco R, Ginestra G, D'amico R, Bisignano C, Mandalari G, et al. Involvement of TLR4 and PPAR- $\alpha$ receptors in host response and NLRP3 inflammasome activation, against pulmonary infection with pseudomonas aeruginosa. Shock. (2019) 51:221-7. doi: 10.1097/SHK.0000000000001137

80. Lerner AG, Upton J-P, Praveen P, Ghosh R, Nakagawa Y, Igbaria A, et al. IRE1 $\alpha$ induces thioredoxin-interacting protein to activate the NLRP3 inflammasome and promote programmed cell death under irremediable ER stress. Cell Metabol. (2012) 16:250-64. doi: 10.1016/j.cmet.2012.07.007

81. Giorgi C, Ito K, Lin H-K, Santangelo C, Wieckowski MR, Lebiedzinska $\mathrm{M}$, et al. PML regulates apoptosis at endoplasmic reticulum by modulating calcium release. Science. (2010) 330:1247-51. doi: 10.1126/science.1189157

82. Zhou R, Yazdi AS, Menu P, Tschopp J. A role for mitochondria in NLRP3 inflammasome activation. Nature. (2011) 469:221-5. doi: $10.1038 /$ nature09663

83. Wang W, Wang X, Chun J, Vilaysane A, Clark S, French G, et al. Inflammasome-independent NLRP3 augments TGF- $\beta$ signaling in kidney epithelium. J Immunol. (2013) 190:1239-49. doi: 10.4049/jimmunol.1201959

84. Bracey NA, Gershkovich B, Chun J, Vilaysane A, Meijndert HC, Wright JR, et al. Mitochondrial NLRP3 protein induces reactive oxygen species to promote Smad protein signaling and fibrosis independent from the inflammasome. J Biol Chem. (2014) 289:19571-84. doi: 10.1074/jbc.M114.550624

85. Rajamäki K, Mäyränpää MI, Risco A, Tuimala J, Nurmi K, Cuenda A, et al. p38 MAPK: a novel regulator of NLRP3 inflammasome activation with increased expression in coronary atherogenesis. Arterioscler Thromb Vascul Biol. (2016) 36:1937-46. doi: 10.1161/ATVBAHA.115.307312

86. Brew K, Dinakarpandian D, Nagase H. Tissue inhibitors of metalloproteinases: evolution, structure and function. Biochim Biophys Acta. (2000) 1477:267-83. doi: 10.1016/S0167-4838(99)00279-4

87. Nothnick WB. Disruption of the tissue inhibitor of metalloproteinase-1 gene results in altered reproductive cyclicity and uterine morphology in reproductive-age female mice. Biol Reproduc. (2000) 63:905-12. doi: 10.1095/biolreprod63.3.905

88. Kim Y-S, Kim S-H, Kang J-G, Ko J-H. Expression level and glycan dynamics determine the net effects of TIMP-1 on cancer progression. BMB Rep. (2012) 45:623. doi: 10.5483/BMBRep.2012.45. 11.233

89. Liu K-H, Zhou N, Zou Y, Yang Y-Y, Ouyang S-X, Liang Y-M. Spleen Tyrosine Kinase (SYK) in the Progression of Peritoneal 
Fibrosis Through Activation of the TGF- $\beta 1 / \mathrm{Smad} 3$ Signaling Pathway. Med Sci Monitor. (2019) 25:9346. doi: 10.12659/MSM.9 17287

90. Islam MT, Silva CB, Alencar MVOB, Paz MFCJ, Almeida FRC, Melo-Cavalcante AAC. Diterpenes: advances in neurobiological drug research. Phytother Res. (2016) 30:915-28. doi: 10.1002/ptr. 5609

91. Freeman TL, Swartz TH. Targeting the NLRP3 inflammasome in Severe COVID-19. Front Immunol. (2020) 11:1518. doi: 10.3389/fimmu.2020. 01518

92. Islam MT, Sarkar C, El-Kersh DM, Jamaddar S, Uddin SJ, Shilpi JA, et al. Natural products and their derivatives against coronavirus: a review of the non-clinical and pre-clinical data. Phytother Res. (2020). doi: 10.1002/ptr.6700

93. Orhan IE, Deniz FSS. Natural products as potential leads against coronaviruses: could they be encouraging structural models against SARS-CoV-2? Nat Products Bioprospect. (2020) 10:171-86. doi: 10.1007/s13659-020-00250-4

Conflict of Interest: The authors declare that the research was conducted in the absence of any commercial or financial relationships that could be construed as a potential conflict of interest.

Copyright (c) 2020 Islam, Bardaweel, Mubarak, Koch, Gawel-Beben, Antosiewicz and Sharifi-Rad. This is an open-access article distributed under the terms of the Creative Commons Attribution License (CC BY). The use, distribution or reproduction in other forums is permitted, provided the original author(s) and the copyright owner(s) are credited and that the original publication in this journal is cited, in accordance with accepted academic practice. No use, distribution or reproduction is permitted which does not comply with these terms. 